Journal of Tropical Ecology

http://journals.cambridge.org/TRO

Additional services for Journal of Tropical Ecology:

Email alerts: Click here

Subscriptions: Click here

Commercial reprints: Click here

Terms of use : $\underline{\text { Click here }}$

\title{
Infection intensity, spore density and inoculum potential of arbuscular mycorrhizal fungi decrease during secondary succession in tropical Brazilian ecosystems
}

Waldemar Zangaro, Adrielly Pereira Ansanelo, Luis Eduardo Azevedo Marques Lescano, Ricardo de Almeida Alves, Artur Berbel Lírio Rondina and Marco Antonio Nogueira

Journal of Tropical Ecology / Volume 28 / Issue 05 / September 2012, pp 453 - 462

DOI: 10.1017/S0266467412000399, Published online:

Link to this article: http://journals.cambridge.org/abstract_S0266467412000399

How to cite this article:

Waldemar Zangaro, Adrielly Pereira Ansanelo, Luis Eduardo Azevedo Marques Lescano, Ricardo de Almeida Alves, Artur Berbel Lírio Rondina and Marco Antonio Nogueira (2012). Infection intensity, spore density and inoculum potential of arbuscular mycorrhizal fungi decrease during secondary succession in tropical Brazilian ecosystems. Journal of Tropical Ecology,28, pp 453-462 doi:10.1017/S0266467412000399

Request Permissions : $\underline{\text { Click here }}$ 


\title{
Infection intensity, spore density and inoculum potential of arbuscular mycorrhizal fungi decrease during secondary succession in tropical Brazilian ecosystems
}

\author{
Waldemar Zangaro*,1, Adrielly Pereira Ansanelo*, Luis Eduardo Azevedo Marques Lescano†, \\ Ricardo de Almeida Alves*, Artur Berbel Lírio Rondina* and Marco Antonio Nogueira† ${ }^{2}$
}

\author{
* Universidade Estadual de Londrina, Centro de Ciências Biológicas, Departamento de Biologia Animal e Vegetal, Programa de Pós-Graduação em Ciências Biológicas, \\ 86051-990, Londrina, PR, Brazil \\ † Universidade Estadual de Londrina, Centro de Ciências Biológicas, Programa de Pós-Graduação em Microbiologia, 86051-990, Londrina, PR, Brazil \\ (Accepted 4 May 2012)
}

\begin{abstract}
Little is known about the relationship involving arbuscular mycorrhizal (AM) fungi and functional groups of plants that characterize different phases of tropical succession. We appraised the AM infection intensity of root cortex and spore density in the soil in sites over tropical successional gradients (grassland, secondary forest and mature forest) for several years in Araucaria, Atlantic and Pantanal ecosystems in Brazil. The intensity of AM infection decreased with advancing successional stages in all ecosystems and it was around 60-80\% in early stages of succession, 37-56\% in secondary forests and 19-29\% in mature forests. Similarly, the AM spore number also decreased with advancing succession and was the highest in early stages $\left(73-123 \mathrm{~g}^{-1}\right)$, intermediate in secondary forests $\left(32-54 \mathrm{~g}^{-1}\right)$ and lowest in the mature forests $\left(10-23 \mathrm{~g}^{-1}\right)$. To verify whether such reductions influenced the potential of AM inoculum in soil, seedlings of Heliocarpus popayanensis (Malvaceae) were grown as test plants in soils obtained from five grasslands, five young secondary forests, and five mature forests in the Atlantic ecosystem. The soil inocula from the grasslands and secondary forests were 7.6 and 5.7 times more effective in stimulating seedling growth than inocula from the mature forests, respectively. Our results show that plant species in grasslands and young secondary forests stimulate the multiplication of AM fungi, leading to a higher potential of the AM inoculum. In later-successional stages, plant investment in AM fungi decreases and the potential of the AM inoculum is also reduced.
\end{abstract}

Key Words: grassland, plant functional groups, root infection, secondary forest, soil fertility, succession continuum, symbioses, tropical forest

\section{INTRODUCTION}

Tropical plant succession occurs when light-demanding pioneer and early-secondary tree species replace the earlysuccessional plant communities such as grasses, shrubs and forbs. At later stages of succession, pioneer and early-secondary trees species, which are plants unable to grow and reproduce under their own shade, are replaced by late-secondary and climax species, which are shade tolerant and predominate in closed canopies (Zangaro et al. 2003).

\footnotetext{
${ }^{1}$ Corresponding author. Email: wzangaro@uel.br

${ }^{2}$ Present address: Embrapa Soja, Cx. Postal 231, 86001-970 Londrina, PR, Brazil.
}

Early-successional plant species display higher growth, metabolism, respiration and net assimilation rates, in addition to greater nitrogen concentrations in leaves, higher specific leaf areas with a shorter life span and thicker palisade mesophyll as compared with plants from later phases of succession (Khurana \& Singh 2006). These properties allow the fast-growing species to reach a higher photosynthetic capacity (Lusk et al. 2008), which increases the carbon translocation for root growth (Nielsen etal. 1998). Their accelerated metabolism demands higher amounts of nutrients (Lusk et al. 2008) and increased plant investment in fine roots allows higher nutrient uptake. As a consequence, earlysuccessional species produce fine-root systems with a more effective soil exploration capacity, including a longer fine-root length, higher specific root length, fine 
roots with smaller diameters and a lower tissue density (Zangaro et al. 2008), more branching, more root tips per unit of root length and a higher density of longer root hairs than late-successional species (Zangaro et al. 2005, 2012). Such fine-root morphological traits allow more soil exploration with less biomass investment in the fine roots (Zangaro et al. 2007).

Paradoxically, although the tropical seedlings of earlysuccessional woody species have high photosynthetic potential and fine-root morphological traits adapted for a high capacity of nutrient uptake, they are unable to ensure an adequate nutrient supply for the maintenance of their inherent fast growth rate in low-fertility soils unless they are associated with arbuscular mycorrhizal (AM) fungi (Matsumoto etal. 2005, Pasqualini et al. 2007, Pizano et al. 2011, Vandresen et al. 2007, Zangaro et al. 2000, 2003, 2005, 2007). The AM hyphae explore a given volume of soil more extensively and more effectively than roots, contributing toward increasing the root uptake potential (Brundrett 2002). On the other hand, most tropical seedlings of late-successional woody species, despite having a low photosynthetic rate and fine-root morphological traits that are less well adapted for nutrient uptake, are able to grow in low-fertility soils without AM fungi (Zangaro et al. 2007). Therefore, tropical fast-growing plant species are more reliant on AM-fungal association than slow-growing ones. In adult plants under field conditions, the degree of fine-root infection and spore density in soils with a high occurrence of early-successional species were several times greater than in mature forest with a greater abundance of late-secondary and climax species (Zangaro et al. 2008, 2012). The objective of this study was to evaluate the distinct investment in AM association between different functional groups of plants. Thus, AM-infection intensity in root cortex and spore density in soil were assessed over several years in some Brazilian ecosystems representing a chronosequence of tropical succession in the Araucaria, Atlantic and Pantanal ecosystems. In addition, the $\mathrm{AM}$ fungus inoculum potential in the soils from five grasslands, five young secondary forests, and five mature forests from the Atlantic ecosystem and their influence on the initial growth of the mycotrophic pioneer native woody species Heliocarpuspopayanensis was evaluated. We hypothesize that the AM-root infection intensity, AM-spore density and AM-soil inoculum potential gradually decrease during tropical succession.

\section{METHODS}

\section{Study sites}

The sites studied are situated in the Araucaria, Atlantic and Pantanal ecosystems. The study sites in the Araucaria ecosystem are located at the Klabin Ecological Park in
Telêmaco Borba county, Paraná state, southern Brazil $\left(24^{\circ} 20^{\prime} \mathrm{S}, 50^{\circ} 37^{\prime} \mathrm{W}\right)$. The soil samples were assessed during the plant growing season (March) in 2006, 2007 and 2008 in a grassland site, secondary 15-y-old forest, secondary 30-y-old forest, secondary 50-y-old forest and a mature forest.

The study sites in the Atlantic ecosystem are located in Londrina county, Paraná state, southern Brazil $\left(23^{\circ} 27^{\prime} \mathrm{S}\right.$, $\left.51^{\circ} 15^{\prime} \mathrm{W}\right)$. The soil samples were assessed during the plant growing season (January-February) in 2005, 2006, 2007 and 2008 in a grassland site, scrub 5-y-old vegetation, secondary 20 -y-old forest and a mature forest.

The study sites in the Pantanal ecosystem are located on a seasonally flooded plain of the Miranda river, southern Pantanal, Mato Grosso do Sul state, mid-western Brazil $\left(20^{\circ} 25^{\prime} \mathrm{S}, 57^{\circ} 28^{\prime} \mathrm{W}\right)$. The soil samples were taken during the plant growing season (January-February) in 2003, 2004 and 2007 in a grassland site, secondary 15-y-old forest and a mature forest. Further details on descriptions of all ecosystems are given in Zangaro et al. (2012).

\section{Field sampling and soil characteristics}

We established three $10 \times 50-\mathrm{m}$ plots in sites representative of each successional phase and respective ecosystem. Each plot was subdivided into five $10 \times 10-\mathrm{m}$ subplots and two sample points were placed at random within each subplot, according to Powers et al. (2005). Ten soil cores ( $45 \mathrm{~mm}$ in diameter and $100 \mathrm{~mm}$ in depth) were randomly collected in each plot at a $0-10 \mathrm{~cm}$ depth, amounting to 30 samples per site of each successional phase for the Araucaria and Pantanal ecosystems. For the Atlantic ecosystem, soil cores $(40 \mathrm{~mm}$ in diameter and $50 \mathrm{~mm}$ in depth) were taken at a $0-5 \mathrm{~cm}$ depth. For each successional site, 15 soil cores were labelled and stored at $5{ }^{\circ} \mathrm{C}$ for extraction of the fine roots. The remaining 15 soil cores were air-dried and used for counting the number of AM fungal spores and for chemical analysis. The carbon was oxidized with $2 \mathrm{M} \mathrm{Na}_{2} \mathrm{Cr}_{2} \mathrm{O}_{7}$ in $5 \mathrm{M}$ $\mathrm{H}_{2} \mathrm{SO}_{4}$ and determined by colorimetry. Calcium and magnesium were extracted with $1 \mathrm{M} \mathrm{KCl}$ and determined by titration. Phosphorus and potassium were extracted using Mehlich-1 and determined using colorimetry and flame photometry, respectively. The available mineral $\mathrm{N}$ $\left(\mathrm{NH}_{4}{ }^{+}+\mathrm{NO}_{3}{ }^{-}\right)$was extracted with $2 \mathrm{M} \mathrm{KCl}$, followed by semi-micro Kjeldahl distillation and titration.

We extracted fine roots from the soil cores after soaking the root fragments in tap water and separating them by sieving with a $0.25-\mathrm{mm}$ mesh sieve. The material retained on the sieve was hand-sorted into shallow dishes underwater; living fine-root segments $(<2 \mathrm{~mm}$ diameter $)$ were fixed in FAA ( $5 \mathrm{~mL}$ formaldehyde, $5 \mathrm{~mL}$ acetic acid and $90 \mathrm{~mL} 50 \%$ ethanol) and stored until analysis.

The AM-infection intensity was determined on fine roots after clarification $(10 \% \mathrm{KOH})$, acidification $(1 \%$ 
$\mathrm{HCl})$, washing in tap water, and staining $(0.05 \%$ trypan blue) (Brundrett et al. 1996). For some darkly pigmented root fragments from secondary and mature forests, we used $0.5 \% \mathrm{H}_{2} \mathrm{O}_{2}$ after $\mathrm{KOH}$. The intensity of fine-root infection by AM fungi was assessed by the grid-line intersection method (Giovannetti \& Mosse 1980) using a dissecting microscope at a magnification lower than $\times 100$ and expressed as percentage root infection; only aseptate hyphae were considered as AM colonizers of the root cortex. No attempt was made to determine the AM fungal structures separately, such as the inter- and intracellular hyphae, vesicles or arbuscules.

The AM spores were extracted from $20 \mathrm{~g}$ of soil in each homogenized sample using the wet-sieving technique (sieves from $710 \mu \mathrm{m}$ to $53 \mu \mathrm{m}$ ), and flotation in sucrose (Brundrett etal. 1996). The spores were recovered, washed in water, and spread upon gridded filter paper and all apparently healthy AM spores were counted under a dissecting microscope at a magnification less than $\times 40$.

\section{Evaluation of the AM fungal inoculum potential}

We evaluated the AM fungal inoculum potential in the soils from five grasslands, five young secondary forests and five mature forests from the Atlantic ecosystem on the initial growth of seedlings of the mycotrophic pioneer native woody species Heliocarpus popayanensis Kunth (Malvaceae). Fifteen sites belonging to different successional stages were selected during September 2008 in Londrina county, Paraná state, in the Atlantic ecosystems, southern Brazil. Five sites were characterized as early-successional stages and were mainly under herbaceous vegetation, particularly different grass species such as Cynodon dactylon (L.) Pers., Elionurus candidus (Trin.) Hack., Cenchrus echinatus L., Melinis minutiflora P. Beauv., Panicum maximum Jacq. and Pennisetum purpureum Schumach. Other herbaceous plants of the families Asclepiadaceae, Compositae, Cucurbitaceae, Fabaceae, Labiatae, Malvaceae and Piperaceae were also present. Some shrubs such as Cassia patellaria DC. ex Collad., Phytolacca thyrsiflora Fenzl ex Schmidt and Rosmarinus officinalis L. also occurred. This vegetation regenerated after field abandonment due to different, unsuccessful agronomic cultures. These sites were classified as: Early 1, abandoned after coffee, Early 2, abandoned after maize, Early 3, abandoned after soybean, Early 4, abandoned after maize, and Early 5, abandoned after beans. Another five sites were characterized as young secondary forests, principally composed of pioneer and early secondary woody species, which replaced the previous plant communities that belonged to early-successional phases. These secondary forest sites were classified as: Secondary 1 with 30y-old, Secondary 2 with 28 -y-old, Secondary 3 with 25-y-old, Secondary 4 with 25 -y-old and Secondary 5 with 20-y-old stands. The most common tree species in the secondary forests are: Alchornea triplinervia (Spreng.) Müll.Arg., Anadenanthera colubrina (Vell.) Brenan, Cedrela fissilis Vell., Citharexylum myrianthum Cham., Croton floribundus Spreng., Heliocarpus americanus L., Jacaranda puberula Cham., Luehea speciosa Willd., Machaerium stipitatum (DC.) Vogel, Parapiptadenia rigida (Benth.) Brenan, Tabernaemontana australis Müll.Arg. and Solanum granuloso-leprosum Dunal. Finally, five sites were characterized as mature forests, principally composed of late-secondary and climax woody species. These intact mature forest sites were classified as: Mature 1 named Mata do Bruno Godoy, Mature 2 named Mata dos Godoy State Park northern part, Mature 3 named Mata dos Godoy State Park southern part, Mature 4 named Mata do Bule northern part, and Mature 5 named Mata do Bule southern part. These mature forest sites are primary, tropical and semi-deciduous forests that are very rich in plant species. The most common tree species are: Actinostemon concolor (Spreng.) Müll.Arg., Aspidosperma polyneuron Müll.Arg., Astronium graveolens Jacq., Balfourodendron riedelianum (Engl.) Engl., Campomanesia xanthocarpa Mart. ex O. Berg, Cedrela fissilis Vell., Euterpe edulis Mart., Gallesia integrifolia (Spreng.) Harms, Guarea kunthiana A. Juss., Prunus sellowii Koehne, Sorocea bonplandii (Baill.) Burg.Lanj. \& Boer, Trichilia casaretti C. DC. and Vitex montevidensis Cham.

We established three $10 \times 50-\mathrm{m}$ plots in each site that were subdivided into five $10 \times 10-\mathrm{m}$ subplots. Two soil core samples $(150 \mathrm{~mm}$ in diameter and $50 \mathrm{~mm}$ in depth) were collected in each subplot, amounting to 30 samples per site, which were placed in plastic bags. For each site, 15 soil cores were labelled and stored at $5{ }^{\circ} \mathrm{C}$ for fine-root extraction and determination of AM root colonization. The remaining 15 soil cores were air-dried at room temperature and used for counting the number of AM fungal spores and for the soil chemical analysis. Prior to sample processing, each soil sample was homogenized and $50 \mathrm{~g}$ of fresh soil of each sample belonging to the same site was taken out, and thus 30 samples from the same site were pooled. We obtained $1500 \mathrm{~g}$ of soil, which was thoroughly homogenized. Using this procedure, we obtained an AM-fungal soil inoculum including fine roots, soil hyphae and spores from each study site.

Fifty grams of the AM-fungal soil inoculum was placed in small plastic nursery tubes $50 \mathrm{~cm}^{3}$ in volume and $100 \mathrm{~mm}$ in depth. One seedling of Heliocarpus popayanensis, $5 \mathrm{~cm}$ in height and pre-germinated in sterilized sand, was planted in a small hole on top of each AM soil inoculum. The nursery tubes were placed in a greenhouse for $40 \mathrm{~d}$. For the control group, a mixture of soil samples from all of the sites studied was sterilized with steam for $72 \mathrm{~h}$ to eliminate AM fungal propagules. Heliocarpus popayanensis was chosen because it is a tropical pioneer tree frequently used in 
Table 1. Soil chemical properties of the Araucaria, Atlantic and Pantanal ecosystems, and field sites for AM fungal inoculum potential and infertile soil for Heliocarpus popayanensis growth. Soils used for evaluation of the AM inoculum potential belonging to the same successional site were mixed among them. In Araucaria ecosystem, Sec 15 (15-y-old secondary forest), Sec 30 (30-y-old secondary forest) and Sec 50 (50-y-old secondary forest). Data are mean \pm SD of three replicates.

\begin{tabular}{|c|c|c|c|c|c|c|c|}
\hline & \multirow{2}{*}{$\begin{array}{c}\mathrm{pH} \\
\mathrm{CaCl}_{2}\end{array}$} & $\mathrm{P}$ & $\mathrm{N}$ & \multirow{2}{*}{$\begin{array}{c}\mathrm{C} \\
\left(\mathrm{g} \mathrm{dm}^{-3}\right)\end{array}$} & \multirow{2}{*}{\multicolumn{3}{|c|}{$\frac{\mathrm{Mg}}{\left(\mathrm{cmol}(+) \mathrm{dm}^{-3}\right)}$}} \\
\hline & & \multicolumn{2}{|c|}{$\left(\mathrm{mg} \mathrm{dm}^{-3}\right)$} & & & & \\
\hline \multicolumn{8}{|c|}{ Succession in Araucaria ecosystem } \\
\hline Grassland & $5.93 \pm 0.34$ & $2.64 \pm 0.44$ & $4.95 \pm 0.47$ & $12.6 \pm 1.92$ & $9.2 \pm 0.98$ & $3.06 \pm 0.42$ & $0.71 \pm 0.26$ \\
\hline $\operatorname{Sec} 15$ & $5.86 \pm 0.44$ & $4.81 \pm 0.79$ & $7.68 \pm 0.93$ & $20.6 \pm 3.42$ & $14.2 \pm 2.95$ & $4.01 \pm 0.91$ & $0.75 \pm 0.21$ \\
\hline $\operatorname{Sec} 30$ & $6.11 \pm 0.26$ & $4.68 \pm 0.89$ & $10.1 \pm 2.14$ & $23.9 \pm 2.67$ & $17.6 \pm 3.17$ & $4.74 \pm 0.79$ & $0.97 \pm 0.12$ \\
\hline $\operatorname{Sec} 50$ & $5.51 \pm 0.36$ & $5.44 \pm 0.92$ & $12.9 \pm 1.91$ & $28.4 \pm 3.75$ & $18.1 \pm 3.21$ & $4.36 \pm 1.02$ & $1.12 \pm 0.31$ \\
\hline Mature & $5.87 \pm 0.24$ & $5.95 \pm 1.12$ & $11.8 \pm 1.36$ & $36.6 \pm 3.43$ & $19.6 \pm 2.72$ & $5.26 \pm 0.83$ & $1.27 \pm 0.56$ \\
\hline \multicolumn{8}{|c|}{ Succession in Atlantic ecosystem } \\
\hline Grassland & $5.47 \pm 0.18$ & $1.89 \pm 0.24$ & $3.72 \pm 0.44$ & $9.84 \pm 3.19$ & $2.53 \pm 0.64$ & $2.20 \pm 0.21$ & $0.38 \pm 0.10$ \\
\hline Scrub & $5.82 \pm 0.39$ & $16.5 \pm 6.81$ & $8.26 \pm 2.42$ & $44.6 \pm 7.11$ & $10.4 \pm 2.48$ & $4.13 \pm 0.23$ & $0.84 \pm 0.23$ \\
\hline Secondary & $5.45 \pm 0.18$ & $5.23 \pm 1.02$ & $11.1 \pm 0.64$ & $51.4 \pm 1.73$ & $10.9 \pm 1.65$ & $4.02 \pm 0.35$ & $0.64 \pm 0.21$ \\
\hline Mature & $5.47 \pm 0.43$ & $4.66 \pm 0.68$ & $14.5 \pm 0.70$ & $51.7 \pm 5.72$ & $9.83 \pm 1.93$ & $3.29 \pm 0.57$ & $0.51 \pm 0.13$ \\
\hline \multicolumn{8}{|c|}{ Succession in Pantanal ecosystem } \\
\hline Grassland & $4.73 \pm 1.14$ & $5.36 \pm 0.75$ & $5.92 \pm 0.61$ & $13.5 \pm 1.73$ & $8.66 \pm 1.17$ & $1.75 \pm 0.58$ & $0.22 \pm 0.11$ \\
\hline Secondary & $4.90 \pm 0.83$ & $5.26 \pm 0.59$ & $8.85 \pm 0.91$ & $15.6 \pm 1.25$ & $6.25 \pm 0.79$ & $2.17 \pm 0.64$ & $0.14 \pm 0.08$ \\
\hline Mature & $4.71 \pm 0.91$ & $9.49 \pm 0.93$ & $11.6 \pm 1.10$ & $26.2 \pm 2.53$ & $7.28 \pm 1.18$ & $3.91 \pm 0.76$ & $0.46 \pm 0.22$ \\
\hline \multicolumn{8}{|c|}{ Field soils for AM inoculum potential determination } \\
\hline Early & $6.23 \pm 0.31$ & $7.11 \pm 2.92$ & $6.23 \pm 1.87$ & $26.8 \pm 3.21$ & $9.26 \pm 2.15$ & $3.28 \pm 1.05$ & $0.61 \pm 0.12$ \\
\hline Secondary & $5.91 \pm 0.26$ & $6.14 \pm 1.25$ & $7.39 \pm 2.03$ & $46.2 \pm 6.22$ & $12.1 \pm 1.29$ & $3.94 \pm 0.49$ & $0.80 \pm 0.26$ \\
\hline Mature & $5.67 \pm 0.14$ & $8.24 \pm 2.06$ & $13.8 \pm 1.33$ & $49.7 \pm 8.24$ & $11.8 \pm 1.93$ & $4.14 \pm 0.86$ & $0.63 \pm 0.21$ \\
\hline Infertile soil & $5.26 \pm 0.18$ & $1.66 \pm 0.24$ & $1.24 \pm 0.44$ & $2.82 \pm 0.19$ & $2.27 \pm 0.64$ & $1.46 \pm 0.21$ & $0.26 \pm 0.10$ \\
\hline
\end{tabular}

forest restoration and is highly responsive to mycorrhizal inoculation (Vandresen et al. 2007, Zangaro et al. 2003). After the growth period, the seedlings and soil adhering to the roots were transplanted to black plastic bags containing $1500 \mathrm{~g}$ of low-fertility soil that was previously sterilized with steam for $72 \mathrm{~h}$ and rested for 3 mo before use. Thus, one seedling grown in each inoculated soil was placed in the transplanting hole in the cultivation bags filled with sterilized low-fertility soil. Thus, there were 15 treatments consisting of different AM inoculum sources in addition to the non-mycorrhizal control, with 10 replicates. The bags were randomly distributed in the greenhouse and the plants were grown for 3 mo during the warm season, under uncontrolled temperature conditions. All seedlings were watered once, daily.

After the plant growth period, all seedlings from each treatment were removed from bags and carefully washed in water. The root and shoot parts were separated, dried $\left(60^{\circ} \mathrm{C}\right)$, and weighed. For each sample, $1 \mathrm{~g}$ of fresh fine roots of approximately $1 \mathrm{~cm}$ length from both mycorrhizal and non-mycorrhizal plants was fixed in FAA and stored for the subsequent analysis of mycorrhizal infection intensity.

\section{Data analyses}

The AM-root infection intensity and spore density from each ecosystem are presented as mean \pm SE for each sampling year. The data were submitted to one-way ANOVA, followed by mean comparisons between the successional sites with Tukey's test at significance levels of 0.05. All data were tested for normal distribution using the Kolmogorov-Smirnov test. The percentage data were transformed to arcsine of square root values, and shoot dry mass data for $H$. popayanensis was log-transformed before analysis. Pearson's correlation analysis between AM-root infection intensity and AM spore density was compared with the means obtained for each sampling site, for each ecosystem and sampling year. Pearson's correlations were also performed for dry shoot matter and mycorrhizal root infection intensity of $H$. popayanensis with the AM fungal variables obtained in the field.

\section{RESULTS}

Soil fertility increased with advancing successional stage in all of the ecosystems (Table 1). Generally, the mature forests had better chemical fertility parameters, followed by soils from secondary forests and grassland sites. The same tendency was observed in the soils used for the assessment of AM fungal inoculum potential. The chemical fertility of the soil used for growing $H$. popayanensis was naturally low.

The mycorrhizal root infection intensity progressively decreased with advancing successional stage in all ecosystems and was very high (60-80\%) in ecological groups belonging to the early stages of succession, such as grassland and scrub sites, followed by secondary forests (37-56\%), and mature forests with the lowest values (1929\%) (Figure 1). 

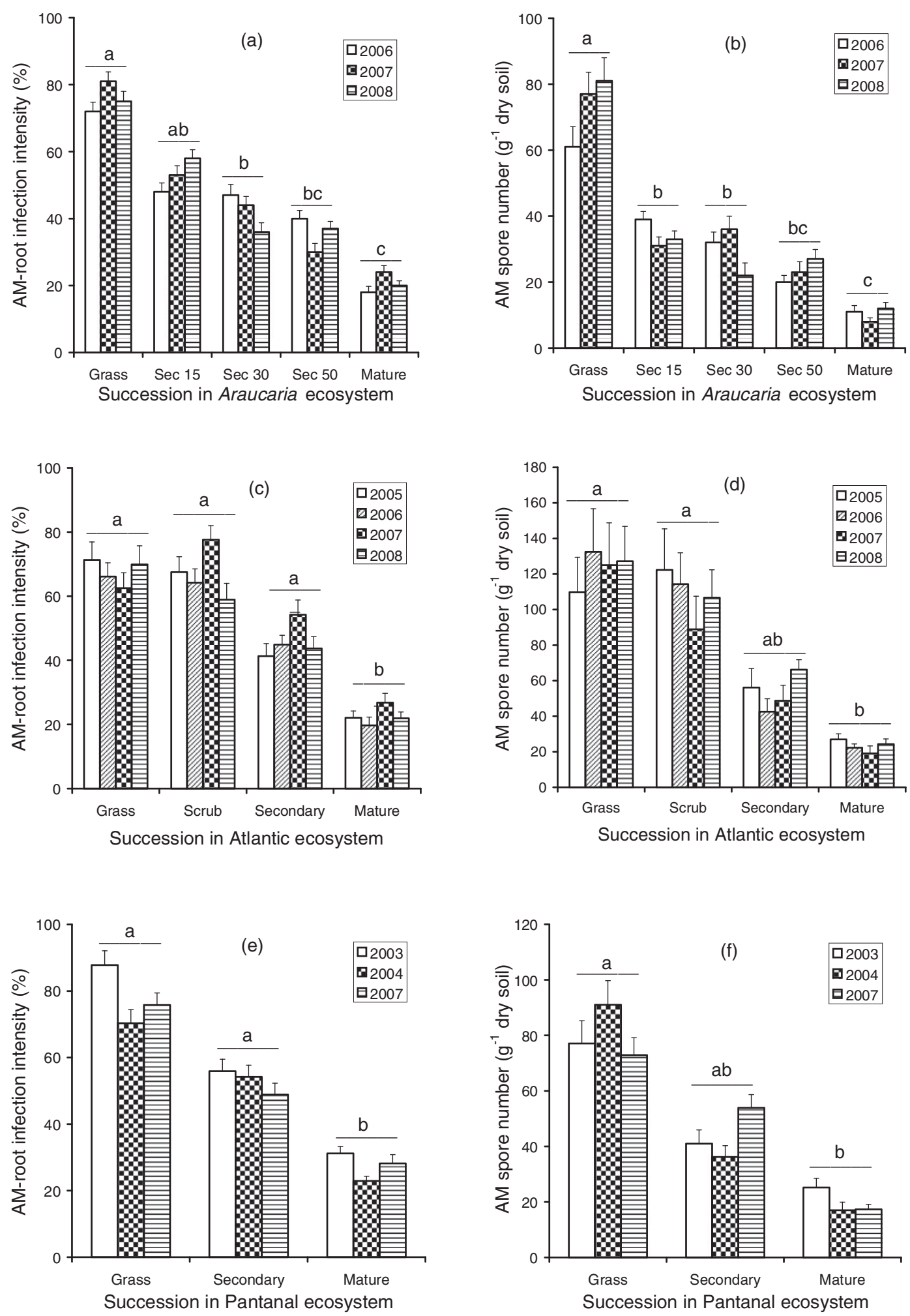

Figure 1. Mycorrhizal root infection intensity and mycorrhizal spore number over several years from Araucaria ecosystem (a, b), Atlantic ecosystem (c, d) and Pantanal ecosystem (e, f) in Brazil. In Araucaria ecosystem Grass (grassland site), Sec 15 (15-y-old secondary forest), Sec 30 (30-y-old secondary forest), Sec 50 (50-y-old secondary forest) and Mature (mature forest). In Atlantic ecosystem Grass (grassland site), Scrub (5-y-old scrub vegetation), Secondary (20-y-old secondary forest) and Mature (mature forest). In Pantanal ecosystem Grass (grassland site), Secondary (15-y-old secondary forest) and Mature (mature forest). Error bars are + SE of the means $(n=15)$. Means followed by the same letter among successional sites are not different by Tukey's test at 0.05 level. 

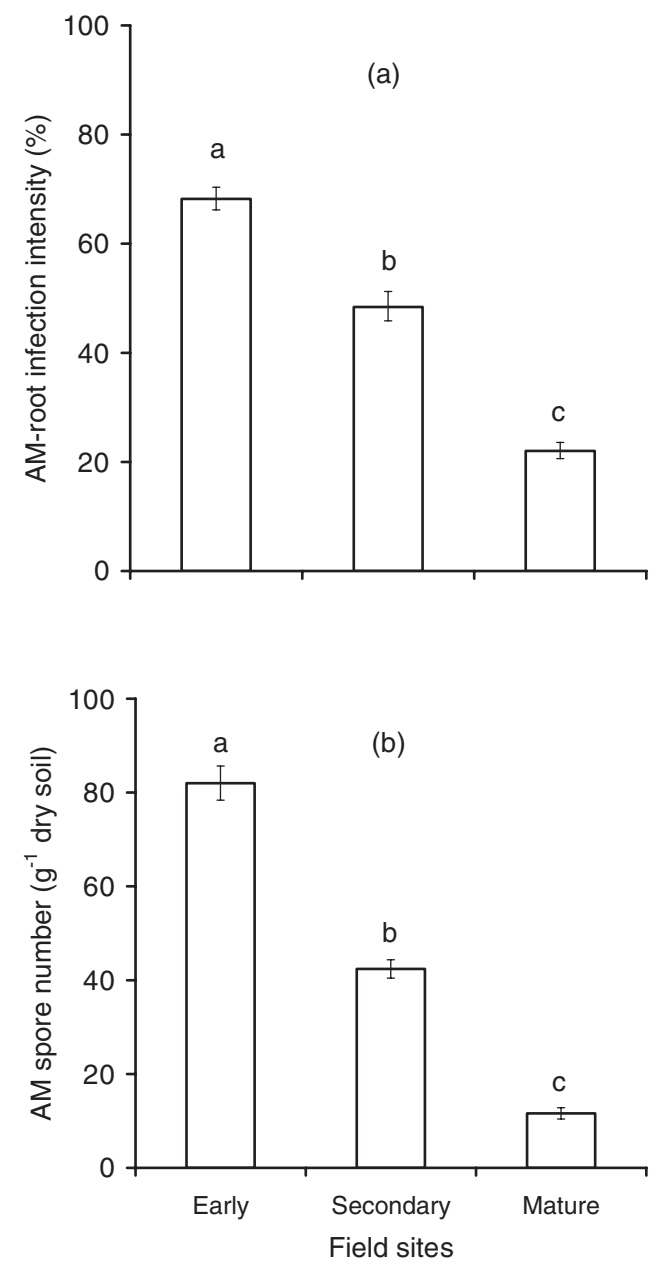

Figure 2. AM-root infection intensity (a) and AM-fungal spore number (b) from five sites of the early-successional phases, five secondary forests and five mature forests, belonging to Atlantic ecosystem in Brazil, used as inoculum for initial seedlings growth. Error bars are \pm SE of the mean $(n=5)$. Means followed by the same letter among successional sites are not different by Tukey's test at 0.05 level.

The total number of AM fungal spores in the soil also decreased with advancing successional stage and, similarly to root colonization, was highest in grassland and scrub sites $\left(73-123 \mathrm{~g}^{-1}\right)$, intermediate in secondary forests $\left(32-54 \mathrm{~g}^{-1}\right)$ and lowest in the mature forests sites $\left(10-23 \mathrm{~g}^{-1}\right)$ (Figure 1).

The percentage of AM-root infection intensity and the total number of AM spores in the soil samples used for the evaluation of AM fungal inoculum potential in the Atlantic ecosystem decreased with the advancing successional stage (Figure 2). The AM-root infection intensity was highest in sites belonging to early stages of succession (62-74\%), intermediate for secondary forests (41-57\%) and lowest in the mature forests (18-27\%). The number of AM fungal spores in the soil was highest in sites from early stages of succession $\left(75-91 \mathrm{~g}^{-1}\right)$, intermediate
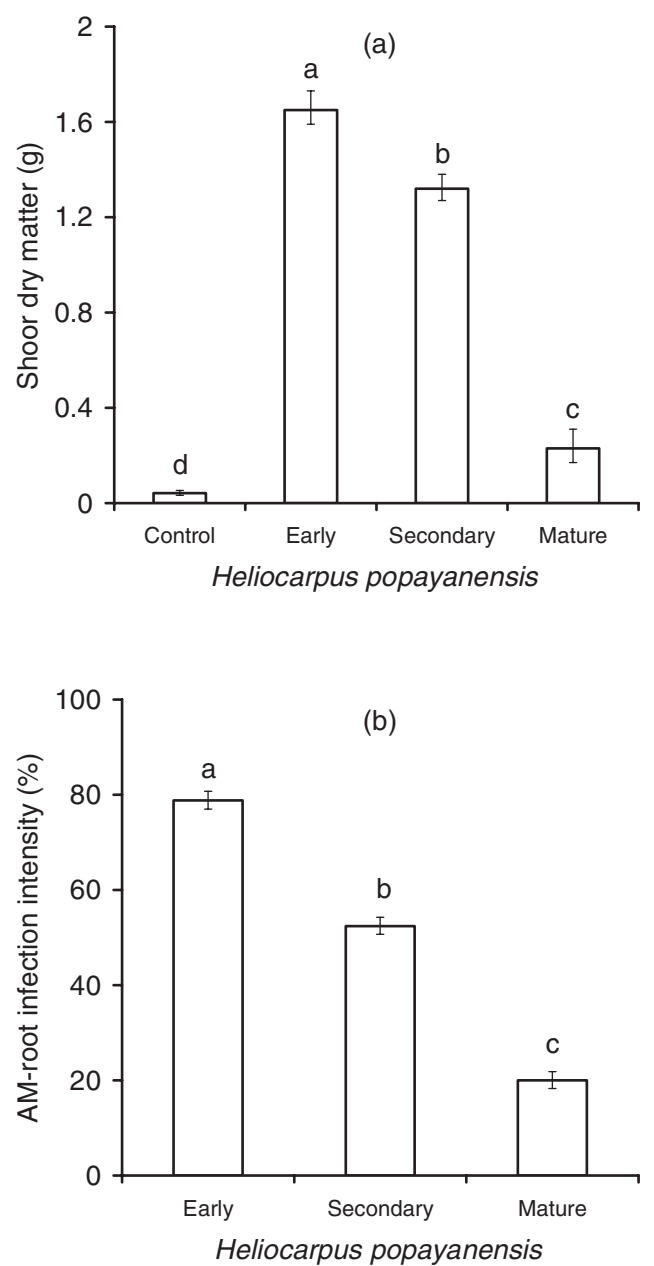

Figure 3. Shoot dry matter (a) and AM-root infection intensity (b) of Heliocarpus popayanensis seedlings planted in black plastic bags filled with sterilized low-fertility soil. The seedlings growth previously in small nursery tubes with different soil inocula obtained in five sites from early succession phases, five sites from secondary forests and five sites from mature forests, belonging to Atlantic ecosystem in Brazil. Controlsterilized soil has no AM fungi propagules. Error bars are $\pm \mathrm{SE}$ of the mean $(n=5)$. Means followed by the same letter among successional sites are not different by Tukey's test at 0.05 level.

in secondary forests $\left(38-48 \mathrm{~g}^{-1}\right)$ and lowest in mature forests $\left(9-16 \mathrm{~g}^{-1}\right)$ (Figure 2).

The shoot dry mass produced by $H$. popayanensis previously grown for $40 \mathrm{~d}$ in the original soils used as the inoculum and later grown in sterilized low-fertility soil, were $1.75 \mathrm{~g}$ in soil inocula from early-successional sites, $1.32 \mathrm{~g}$ from secondary forests, $0.23 \mathrm{~g}$ from mature forests and $0.04 \mathrm{~g}$ in control soil without AM fungi (Figure 3a). In this case, the soil inocula from the early-successional sites and secondary forests were 7.6 and 5.7 times more effective in stimulating seedling growth than inocula from the mature forests, respectively. Accordingly, the AMroot infection intensity in seedlings of $H$. popayanensis was the highest $(73-84 \%)$ when inoculated with soil 
from the sites of early succession as the inoculum source, intermediate (49-58\%) when inoculated with AM fungi from secondary forests, and the lowest (14-24\%) when inoculated with soil from mature forests as the source of AM fungi (Figure 3b). Roots from control plants that were not inoculated did not display AM fungal colonization.

Based on Pearson's correlation analysis, the AM-root infection intensity and spore density in the soils showed a positive correlation in the Araucaria ecosystem $(r=0.93$, $\mathrm{P}<0.0001, \mathrm{n}=15)$, in the Atlantic ecosystem $(r=$ $0.89, \mathrm{P}<0.0001, \mathrm{n}=16$ ), in the Pantanal ecosystem $(r=0.90, \mathrm{P}=0.0007, \mathrm{n}=9)$, and in the 15 field sites sampled for $H$. popayanensis inoculation $(r=0.94, \mathrm{P}<$ $0.0001, \mathrm{n}=15$ ). The shoot dry matter production by $H$. popayanensis seedlings displayed a positive correlation with AM-root infection intensity in the greenhouse $(r=$ 0.95, $\mathrm{P}<0.0001, \mathrm{n}=15)$ and with AM-root infection intensity $(r=0.93, \mathrm{P}<0.0001, \mathrm{n}=15)$ and spore density $(r=0.82, \mathrm{P}<0.0001, \mathrm{n}=15)$ in the field. Similar results were found between AM-root infection intensity of $H$. popayanensis grown in the greenhouse and AM-root infection intensity $(r=0.97, \mathrm{P}<0.0001, \mathrm{n}=15)$ and spore density $(r=0.96, \mathrm{P}<0.0001, \mathrm{n}=15)$ found in the field.

\section{DISCUSSION}

\section{Mycorrhizal attributes in early phases of succession}

The AM-root infection intensity and AM spore density in the soil progressively decreased along the plant successional trajectory, from the grassland sites to the mature-forest sites. Plant species from the early successional phases were more susceptible to forming AM symbioses than plants from later successional stages. The early-successional plant species display fast growth rates and a high photosynthetic potential (Khurana \& Singh 2006, Kitajima 1994, Lusk et al. 2008), requiring large amounts of nutrients and consequently a high receptiveness to AM fungi in order to help them to reach their inherent nutrient demands. In this way, earlysuccessional plant species that frequently grow in lowfertility soils, such as the sites from early successional phases in this study, are probably limited in terms of adequate nutrient acquisition, which makes them more reliant on AM fungi as an alternative for improving their potential for nutrient uptake and for improvements in plant establishment, growth and survival. This plantfungus partnership is consistent with the complete inability of the seedlings of early-successional species to grow when cultivated in low-fertility soils in the absence of AM fungi under greenhouse conditions (Pizano et al. 2011, Zangaro et al. 2003). Nevertheless, once AM fungi colonize the fine roots of early-successional species, plant survival and growth are assured in low-fertility soils, a condition in which AM association is crucial for plant nutrient acquisition. Since fast-growing species display innate adaptation to environments with high light availability, a large quantity of photosynthetic products is produced (Gamage et al. 2004), increasing the carbon available for AM infection and sporulation (Smith \& Read 2008). In addition, the amount of carbon drained from plants to sustain the symbiotic fungi can be sufficiently high to induce the plants to increase their photosynthetic rates (Smith \& Read 2008). As a consequence, more soluble carbon can be produced and exported to the roots, allowing the maintenance of higher AM-root infection intensity, external hyphae, and sporulation among the early-successional plant species, resulting in a greater volume of low-fertility soil to be explored. We believe that the short life span, early flowering, high photosynthetic rate, high light demand and high growth rate are intrinsic characteristics of fast-growing tropical plant species, which can explain the maintenance of high infection intensity of AM fungi on roots. The amplification of the absorptive system using AM fungi can ensure sufficient nutrients for seed production in a short period before the end of their short life cycle.

In ecosystems very similar to the ones studied here, plants from early-successional stages were also observed combining high AM-root infection intensity with fineroot morphology better adapted for more efficient soil exploration and uptake than plants from mature forests (Zangaro et al. 2008, 2012). Since the plant potential for $\mathrm{P}$ uptake via AM fungi is related to the total hyphal length of AM fungi in the soil (Brundrett 2002), under $\mathrm{P}$-limiting conditions, such as in the grassland sites in this study, the inherent fast grow th rate and plant productivity can be reached because more $\mathrm{P}$ can be obtained by means of a suitable fine-root morphology and the larger amounts of external AM hyphae that emanate from the plentiful internal hyphae inhabiting the fine-root cortex. Supporting this statement, a very high density of external hyphae of AM fungi was reported in natural grasslands, amounting to $68-101 \mathrm{~m} \mathrm{~g}^{-1}$ soil in a tallgrass prairie and $45-74 \mathrm{~m} \mathrm{~g}^{-1}$ soil in a pasture (Miller et al. 1995).

\section{Mycorrhizal attributes in late-successional stages}

The low investment in AM symbiosis by plant species of the mature forests is in agreement with their lower nutrient requirements, attributable to the inherently slower metabolism characterized by lower growth rates, a longer life span, lower light requirements, lower photosynthetic potential, and lower metabolic demands (Zangaro et al. 2003). Plant communities in mature forests have denser canopies, experience shaded environments with high competition for light, and generally have lower 
photosynthetic rates (Lusk et al. 2008). A restriction in light availability implies a lower carbon fixation rate, resulting in lower levels of carbon translocation toward the roots, reducing root exudation (Smith \& Read 2008) and the concentration of soluble carbohydrates in the root cortex (Gamage et al. 2004). As a consequence, a restriction in available carbon causes a decline in both AM-root infection intensity and sporulation. In addition, plant energy economy is critical under mature forest conditions due to energy limitations in the shaded environment (Kitajima 1994). As large amounts of plant photosynthetic products can be drained by AM fungi (Nielsen et al. 1998), the costs for plants in mature forests to maintain high amount of AM fungi may be high. Thus, the limitation in the mycorrhizal symbiosis can be an important strategy for plant energy conservation under mature-forest conditions (Zangaro et al. 2012).

In agreement with the results of this study, a progressive decrease in AM spore density and AM-root infection intensity along a tropical plant succession was verified by Zangaro et al. $(2008,2012)$ under field conditions in southern and mid-western Brazil; by Aidar et al. (2004) in a chronosequence of an Atlantic forest in southeastern Brazil; and by Stürmer \& Siqueira (2011) along a succession in the Brazilian Amazonian forest. Picone (2000) recovered more spores from pastures than native tropical forest in Costa Rica and Nicaragua. Fischer et al. (1994) found not only a higher AM spore density but also a higher inoculum potential in grass pasture compared with native forest in Costa Rica. Powers et al. (2005) found an unexpectedly low amount of external AM fungal hyphae in the soils from four tropical mature forests in Central and South America. In addition, the mycorrhizal status of the different functional groups of plants from several ecosystems in the present study corroborated some greenhouse results in which seedlings of pioneer and early-secondary woody species colonized by AM fungi exhibited a greater responsiveness and higher root infection intensity than late-secondary and climax woody species (Pasqualini et al. 2007, Zangaro et al. 2003). These results appear to contradict Janos (1980), who proposed that seedlings of early-successional woody pioneer species were less susceptible and less influenced by AM fungi when compared with seedlings belonging to late-successional woody species under greenhouse conditions, suggesting an increase in the influence of AM fungi during tropical forest succession in Costa Rica.

The typically low demand for nutrients among plant species of later-successional phases is in agreement with their usually low AM-root infection intensity and fineroot morphological traits such as shorter total and specific root lengths, larger root diameter, higher root tissue density, and lower root-hair incidence and length. This low investment in fine roots and restriction of AM fungi result in a low nutrient uptake potential, which is probably the reason for the very low values of external hyphae in soils of several tropical mature forests. Powers et al. (2005) found only $0.16 \mathrm{~m} \mathrm{~g}^{-1}$ soil of AM hyphae in soil from La Selva in Costa Rica, $0.14 \mathrm{~m} \mathrm{~g}^{-1}$ soil in Barro Colorado Island in Panama, and $0.15 \mathrm{~m} \mathrm{~g}^{-1}$ soil in Cocha Cashu in Amazonian Peru. Consequently, the potential of mycorrhizal networks as the primary source of inocula in tropical mature forests can be considered low. Janos (1992) suggested that the very low density of AM spores found in tropical mature forests is related to the stable microclimate in the soil, and that the spread of AM fungi occurs in a root-to-root manner through their external mycelium among the entanglement of roots from different plant species; thus, sporulation is unnecessary. Similarly, Stürmer \& Siqueira (2011) suggested that the low AM spore density in the Amazonian mature forest may be the result of latent fungal associations or of fungi with a preference for vegetative growth instead of partitioning biomass to spores. Based on the range of functional groups of plants throughout tropical succession, we concluded that the low AM spore density in tropical mature forests is a logical consequence of the low amounts of external AM hyphae that emanate from scant hyphae colonizing the root cortices of plants belonging to late-successional woody species.

\section{Implications of the AM inoculum potential for secondary forest formation}

The AM-root infection intensity and AM spore density in the soil were positively correlated with each other in this study. These AM variables have been correlated with mycelial biomass and the length of AM fungi in the soils of different sites (Picone 2000). Different values of AM variables can express the potential of plants to maintain and multiply AM fungi as well the AM inoculum potential encountered in soils under different plant functional groups, reflecting AM propagule density and AM infectivity. Here, we found higher AM-root infection intensity, AM fungal spore density, and soil inoculum potential in soils from grassland and scrub sites, revealing a greater plant capacity for multiplying AM fungi that, besides providing a high inoculum potential for their offspring, can also make this environment more appropriate for the recruitment and installation of the highly mycotrophic fast-growing woody species that are involved in the process of young secondary forest formation. Since these woody species are highly responsive to AM infection, regardless of the natural soil fertility (Zangaro et al. 2007), the aggressiveness of their establishment in open environments can be attributable to the high degree of AM mycotrophy (Zangaro et al. 2003). As a consequence of the high level of AM association and responsiveness in fast-growing woody 
species, Zangaro et al. (2000) suggested that AM fungi may be the main biotic factor affecting the establishment and growth acceleration of native woody species, leading to the initial structuring of tropical secondary forests.

As the level of light limitation increases in the later stages of succession, early successional woody species with typical fast growth rates and shade intolerance have difficulty growing, reproducing and maintaining AM associations due to the low irradiance level and its negative effect on fine-root carbohydrate availability to fungi. Consequently, the reduction in AM fungi at later stages of succession under light limitation is connected to the decrease in shade-intolerant host plant species. Such a decline might have important implications for succession in tropical forests because early successional woody species lose the capacity to maintain AM associations, which results in a limited capacity for the acquisition of water and nutrients, reducing their potential for regeneration, recruitment, and competitive abilities in later successional stages. In these stages, the majority of highly mycotrophic shadeintolerant woody species are replaced by shade-tolerant plant species that predominate under closed canopies and typically have slow growth rates, low nutrient demands and reduced AM associations.

\section{ACKNOWLEDGEMENTS}

The authors would like to thank $\mathrm{CNPq}$ and Empresa Klabin for financial support. Thanks to Edson Mendes Francisco and Biology students at the State University of Londrina for assistance with samplings. Thanks are also due to Empresa Klabin, Universidade Federal do Matogrosso do Sul, and Instituto Ambiental do Paraná for permission for samplings in the Araucaria, Pantanal and Atlantic ecosystems, respectively.

\section{LITERATURE CITED}

AIDAR, M. P. M., CARRENHO, R. \& JOLY, C. A. 2004. Aspects of arbuscular mycorrhizal fungi in an Atlantic Forest chronosequence. Biota Neotropica 4:1-15.

BRUNDRETT, M. 2002. Coevolution of roots and mycorrhizas of land plants. New Phytologist 154:275-304.

BRUNDRETT, M., BEEGHER, N., DELL, B., GROOVE, T. \& MALAJCZUK, N. 1996. Working with mycorrhizas in forestry and agriculture. ACIAR Monograph, Canberra. 374 pp.

FISCHER, C. R., JANOS, D. P., PERRY, D. A. \& LINDERMAN, R. G. 1994. Mycorrhiza inoculum potentials in tropical secondary succession. Biotropica 26:369-377.

GAMAge, H. K., SinghaKumarA, B. M. P. \& ASHTON, M. S. 2004. Effects of light and fertilization on arbuscular mycorrhizal colonization and growth of tropical rain-forest Syzygium tree seedlings. Journal of Tropical Ecology 20:525-534.
GIOVANNETTI, M. \& MOSSE, B. 1980. An evaluation of techniques for measuring vesicular-arbuscular mycorrhizal infections in roots. New Phytologist 84:489-500.

JANOS, D. P. 1980. Mycorrhizae influence tropical succession. Biotropica 12:56-64.

JANOS, D. P. 1992. Heterogeneity and scale in tropical vesiculararbuscular mycorrhiza formation. Pp. 276-282 in Read, D. J., Lewis, D. H., Fitter, A. H. \& Alexander, I. J. (eds). Mycorrhizas in ecosystems. CAB International, Wallingford.

KHURANA, E. \& SINGH, J. S. 2006. Impact of life-history traits on response of seedlings of five tree species of tropical dry forest to shade. Journal of Tropical Ecology 22:653-661.

KITAJIMA, K. 1994. Relative importance of photosynthetic traits and allocation patterns as correlates of seedling shade tolerance of 13 tropical trees. Oecologia 98:419-428.

LUSK, C. H., REICH, P. B., MONTGOMERY, R. A., ACKERLY, D. D. \& CAVENDER-BARES, J. 2008. Why are evergreen leaves so contrary about shade? Trends in Ecology and Evolution 23:299-303.

MATSUMOTO, L. S., MARTINES, A. M., AVANZI, A., ALBINO, U. B., BRASIL, C. B., SARIDAKIS, D. P., RAMPAZO, L. G. L., ZANGARO, W. \& ANDRADE, G. 2005. Interactions among functional groups in the cycling of carbon, nitrogen and phosphorus in the rhizosphere of three successional species of tropical woody trees. Applied Soil Ecology 28:57-65.

MILLER, R. M., REINHARDT, D. R. \& JASTROW, J. D. 1995. External hyphal production of vesicular arbuscular mycorrhizal fungi in pasture and tallgrass prairie communities. Oecologia 103:17-23.

NIELSEN, K. L., BOUMA, T. J., LYNCH, J. P. \& EISSENSTAT, D. M. 1998. Effects of phosphorus availability and vesicular-arbuscular mycorrhizas on the carbon budget of common bean (Phaseolus vulgaris). New Phytologist 139:647-656.

PASQUALINI, D., UHLMANN, A. \& STÜRMER, S. L. 2007. Arbuscular mycorrhizal fungal communities influence growth and phosphorus concentration of woody plants species from the Atlantic rain forest in South Brazil. Forest Ecology and Management 245:148-155.

PICONE, C. 2000. Diversity and abundance of arbuscular-mycorrhizal fungus spores in tropical forest and pasture. Biotropica 32:734750.

PIZANO, C., MANGAN, S. A., HERRE, E. A., EOM, A. \& DALLING, J. W. 2011. Above- and belowground interactions drive habitat segregation between two cryptic species of tropical trees. Ecology 92:47-56.

POWERS, J. S., TRESEDER, K. K. \& LERDAU, M. T. 2005. Fine roots, arbuscular mycorrhizal hyphae and soil nutrients in four neotropical rain forests: patterns across large geographic distance. New Phytologist 165:913-921.

SMITH, S. E. \& READ, D. J. 2008. Mycorrhizal symbiosis. (Third edition). Academic Press, London. 797 pp.

STÜRMER, S. L. \& SIQUEIRA, J. O. 2011. Species richness and spore abundance of arbuscular mycorrhizal fungi across distinct land uses in Western Brazilian Amazon. Mycorrhiza 21:255-267.

VANDRESEN, J., NISHIDATE, F. R., TOREZAN, J. M. D. \& ZANGARO, W. 2007. Inoculação de fungos micorrízicos arbusculares e adubação na formação e pós-transplante de mudas de cinco espécies arbóreas nativas do sul do Brasil. Acta Botanica Brasilica 21:753-765. 
ZANGARO, W., BONONI, V. L. R. \& TRUFEN, S. B. 2000. Mycorrhizal dependency, inoculum potential and habitat preference of native woody species in South Brazil. Journal of Tropical Ecology 16:603622.

ZANGARO, W., NISIZAKI, S. M. A., DOMINGOS, J. C. B. \& NAKANO, E. M. 2003. Mycorrhizal response and sucessional status in 80 woody species from south Brazil. Journal of Tropical Ecology 19:315324.

ZANGARO, W., NISHIDATE, F. R., CAMARGO, F. R. S., ROMAGNOLI, G. G. \& VANDRESEN, J. 2005. Relationships among arbuscular mycorrhizas, root morphology and seedling growth of tropical native woody species in southern Brazil. Journal of Tropical Ecology 21:529540 .
ZANGARO, W., NISHIDATE, F. R., VANDRESEN, J., ANDRADE, G. \& NOGUEIRA, M. A. 2007. Root mycorrhizal colonization and plant responsiveness are related to root plasticity, soil fertility and successional status of native woody species in southern Brazil. Journal of Tropical Ecology 23:53-62.

ZANGARO, W., ASSIS, R. L., MOTTA, A. M., ROSTIROLA, L. V., SOUZA, P. B., GONÇALVES, M. C., ANDRADE, G. \& NOGUEIRA, M. A. 2008. Arbuscular mycorrhizal association and fine root traits changes during succession in southern Brazil. Mycorrhiza 19:37-45.

ZANGARO, W., ALVES, R. A., LESCANO, L. E. A. M., ANSANELO, A. P. \& NOGUEIRA, M. A. 2012. Investment in fine roots and arbuscular mycorrhizal fungi decrease during succession in three Brazilian ecosystems. Biotropica 44:141-150. 